Article

\title{
The Relationship between Economic Freedom and FDI versus Economic Growth: Evidence from the GCC Countries
}

\author{
Hichem Dkhili * and Lassad Ben Dhiab \\ College of Business Administration, Northern Border University, Arar 91431, Saudi Arabia; \\ Lassad.Dhiab@nbu.edu.sa \\ * Correspondence: hichem.dkhili@nbu.edu.sa; Tel.: +966-554-386-129
}

Received: 6 November 2018; Accepted: 18 November 2018; Published: 22 November 2018

\begin{abstract}
This study aims to explain the role of economic freedom in attracting foreign investments and thus raising the level of economic growth. Through a study based on a sample composed of the Gulf Cooperation Council (GCC) countries. A standard model consisting of GCC countries (Saudi Arabia, United Arab Emirates, Qatar, Kuwait, and Oman) was used during the period from 1995 to 2017. We based on the analytical descriptive and secondly, we used a multivariate analysis based on the panel unit root test, the cointegration and finally the regression Fully Modified Ordinary Least Squares (FMOLS) and Dynamic Ordinary Least Squares (DOLS) following the existence of a long-term integration, which includes the modern standard methods to determine the role of economic freedom in raising foreign direct investment and thus economic growth in the second stage. The research findings from GCC countries support the literature, suggesting that there are indeed some indications that greater levels of economic freedom support higher rates of economic growth in a country.
\end{abstract}

Keywords: economic growth; economic freedom; foreign direct investment; panel data

\section{Introduction}

The Gulf Cooperation Council (GCC) countries are generally characterized by the attractiveness of foreign direct investment (FDI) as they have advanced infrastructure and many energy sources. In recent years, these countries have improved their global ranking in the Ease of Doing Business Index for the World Bank, believing in the need to attract foreign investments due to the positive role of these investments in raising the productivity of enterprises and contributing to the transfer of technology and technical expertise. The flow of foreign direct investment has made many thinkers study the effects of these investments on a variety of economic phenomena such as economic growth as a beginning and the relationship with economic freedom later. In the context of encouraging policies to attract foreign investments and opening up to international markets, the importance of this research is considered a serious attempt based on a standard model to study the positive impact and negative impact of attracting foreign direct investment in the GCC countries compared to the economic growth index.

The FDI can even have opposite effects on the economic growth in an environment of trade limitation (Adams 2009) and (Ahmad et al. 2017). Borensztein et al. (1998) demonstrated that, in the host country, the scale of FDI depends on the availability of the stock of human capital. They add that this impact can be showed negative in countries endowed with a low level of human capital. Lamsiraroj (2016) showed that the effect of domination exercised by the foreign firms can discourage the local firms to develop their own activities of Rand. Another negative effect of the FDI can result from the excessive extraction of ores or the concentration of the production on one particular good which would engender a fall in export prices and a deterioration of the terms of exchange for the host country. 
Sayari et al. (2018) and de Haan and Sturm (2000) studies the possibility of a long-run relationship between the Economic Freedom Index (EFI), foreign direct investment (FDI) and value added components of GDP in thirty Eastern, Central, and Western European countries. Their results indicate that there is a marginally significant and negative relationship between EFI and FDI in the random effects model.

In fact, foreign investments play a complementary role to the shortage that may exist in domestic capital. These investments are also important because of their role in the transfer of management, management, marketing and technology in general. These investments are usually accompanied by opportunities to train national cadres and acquire production, marketing and advanced management skills, thereby increasing employment opportunities and increasing the productivity of individuals and institutions.

The aim of this paper is to study the association between FDI, Economic Freedom (EF) and Economic growth (EG). For this reason, we have used data related to GCC countries during the period 1995-2017. In addition to the FDI as a financial variable, trade openness as a proxy of trade, we introduce in our model a proxy of infrastructure (air transport) to explain economic growth.

In this context, our problematic is: What are the determinants of the relationship between the index of economic freedom and foreign direct investment and economic growth?

Finally, this study will be based on the following scheme: First, a review of various modern literary views on economic freedom, foreign direct investment and economic development. Then we will try to give a glimpse of the realities of economic freedom, foreign direct investment and economic growth in the GCC countries through many statistics.

Second, a standard model will be developed to study the relationship between economic freedom, direct foreign investment and economic growth.

\section{Literature Review}

Foreign direct investment (FDI) exerts positive effects on economic growth through various direct and indirect channels. Economic Performance and economic growth of a country is influenced by multiple factors. Foreign direct investment has been observed and argued as a significant determinant. The role of FDI in economic development has been the subject of long debate. The FDI-growth literature has so far yielded mixed results on whether FDI contributes to economic growth.

Girma (2005), explores the effect of FDI on productivity growth by using recently developed threshold regression techniques.

The results mark the presence of nonlinear threshold effects: the productivity benefit from FDI increases with absorptive capacity until some threshold level beyond which it becomes less pronounced. Also, they conclude that there is also a minimum absorptive capacity threshold level below.

Nowak-Lehmann et al. (2012), analyze the relationship between per capita income and foreign aid. And found that foreign aid has a small positive impact on investment, but a significant negative impact on domestic savings (crowding out) and the real exchange rate.

Anwar and Nguyen (2014) study empirically the impact of foreign direct investment (FDI) and FDI generated spillovers on total factor productivity (TFP) in eight regions of Vietnam. Their results prove that the impact of FDI spillovers on TFP varies considerably across regions. In addition, the FDI spillovers generate a strong positive impact on the total factor productivity (TFP).

Ubeda and Pérez-Hernández (2017); Becker et al. (1990) and Doucouliagos and Ulubasoglu (2006) investigate the effect of foreign direct investment on productivity growth in the manufacturing industries of Spain. They advance a theoretical model to test nonlinear relationships between inward FDI and productivity improvement in domestic firms from 1993 to 2006. The results show that FDI is negatively on productivity growth.

The relationship between foreign direct investment and growth has been tested over several samples. Some studies have discussed this relationship overlarge samples, in fact Lee and Chang (2009) tested the interaction between FDI, financial development and economic growth in 37 countries for the period 1970-2002. Empirical results based on the panel Error Correction Model and the Granger Causality test 
reveals respectively evidence of a fairly strong long-run relationship and a weak short-run relationship. Overall, the findings underscore the potential gains associated with FDI when coupled with financial development in an increasingly global economy. Li and Liu (2004) investigated the association FDI-growth in a panel of 84 countries observed during the period of 1970-1999. Using both single equation and simultaneous equation system results show that there is a significant relationship between FDI and economic growth. FDI boosts economic growth directly and also indirectly via human capital, while that of FDI with the technology gap has a significant negative impact. The interaction between FDI and economic growth within the role of financial market has been analyzed, also, by Azman-Saini et al. (2010). Based on a data set for 91 countries over the 1975-2005 periods and applying the threshold regression model, results indicate that the benefit of FDI is non-existent.

Analyzing this relationship in the case of developed and developing countries, Borensztein et al. (1998) tested the effect of FDI on economic growth in 69 developing countries over the last two decades. Empirical results suggest that FDI is a strong mechanism for the transfer of technology, which positively affect growth more than domestic investment. FDI can promote economic growth only when a sufficient absorptive capability of the advanced technologies is available in the host economy. Aurangzeb and Thanasis (2014) examined the relationship between FDI and economic growth in a wide range of developing countries. The time period we cover in this study is from 1970 to 2001 and data for all other variables (real GDP, real gross domestic capital formation, real exports, population, and import price index) are obtained from the World Development Indicators (WDI) of the World Bank. By performing smooth coefficient semi-parametric approach, results show that countries with higher levels of FDI inflows experience higher productivity in the exports sector as compared with those with low level of FDI inflows.

In the case of Latin American countries Bengoa and Sanchez-Robles (2003) and Gwartney (2004) investigated the interaction between economic freedom, foreign direct investment (FDI) and economic growth in 18 countries for 1970-1999. Finding indicates that economic freedom is favorable for FDI inflows. Also, there is a positive correlation between foreign direct investment and economic growth in the host countries. This result can be explained as follow: the host country requires liberalized market, adequate human capital and economic stability to access to long-term capital.

For Asian countries the relationship between FDI and growth was treated. In fact, Chen and Zulkifli (2012) investigated the association between outward FDI and economic growth for Malaysia over the period 1980-2010. By performing a VECM, the results indicate that there exists a positive long-run relationship between FDI and growth as well as long-run bi-directional causation between them. However, there is no Granger-causality in the short-run between outward FDI and growth. For the case of China, Hong (2014) employed a Generalize Method of Moments GMM to analyze this relation in China for the period 1994-2010. The sample is composed from 254 cities in china. Findings indicate that there is a positive association between FDI and economic development.

From the case of the Middle East and North African countries (MENA), Hamdi et al. (2013a) examined the relationship between financial deepening, investment activities and growth for the Tunisian context over the period 1961-2010. In this study, they performed the cointegration method and the Vector Error Correction Model (VECM). Result of short run estimation shows that finance does not promote economic growth. However, there is a positive association between finance and growth in the long-run. In second study, Hamdi et al. (2013b) explored the nexus between FDI and growth in Tunisia over the period 1976-2010.

Cointegration and Vector Error Correction Model and Cointegration techniques reveal that FDI did not have significant impact on growth; however exports are the important source for growth in Tunisia. Belloumi (2014) analyzed the relationship between foreign direct investment (FDI), trade openness and growth in the Tunisian context. Based on the bounds testing (ARDL) approach over the period 1970 to 2008, findings confirm the existence of a long-run relationship between FDI and growth. However, FDI does not granger economic growth in the short run. The empirical results fail to confirm the widespread belief that FDI can generate positive externalities for the case of Tunisia. 
For Gulf countries, Hussein (2009) examined the interaction between foreign direct investment FDI and economic growth in the six GCC countries $^{1}$ during the period 1996-2007. The econometric method used in this study is the Ordinary Least Square (OLS). Major findings indicate a weak relationship between FDI and growth for the sample of the GCC. Almfraji and Almsafir (2014) tested the FDI-growth association in an oil production country. For this end they collected dataset from 1990 to 2010 and they performed VAR Impulse Responses and the Granger Causality test. The result indicates that there a long-run relationship between FDI inflows and the economic growth in Qatar.

The main objective of the study of Al Khathlan (2013) is to empirically analyze the role of FDI in the economic growth of Saudi Arabia from 1980 to 2010. By using the famous Cobb-Douglas production function and performing a co-integration analysis finding indicates that FDI has a positive but insignificant role in economic growth in the country over the long term. However, the Granger causality test implies that domestic capital and government expenditure drive output growth in the economy. This result is also consistent with the IRFs over a time horizon of 10 years.

Bengoa and Sanchez-Robles (2003) explore the interplay between economic freedom, foreign direct investment and economic growth using panel data analysis for a sample of 18 Latin American countries for 1970-1999. And find that economic freedom in the host country is a positive determinant of FDI inflows. Our results also suggest that foreign direct investment is positively correlated with economic growth in the host countries. The host country requires, however, adequate human capital, economic stability and liberalized markets to benefit from long-term capital flows.

Borensztein et al. (1998) test the effect of foreign direct investment (FDI) on economic growth in a cross-country regression framework, utilizing data on FDI flows from industrial countries to 69 developing countries over the last two decades. Their results suggest that FDI is an important vehicle for the transfer of technology, contributing relatively more to growth than domestic investment. However, the higher productivity of FDI holds only when the host country has a minimum threshold stock of human capital. Thus, FDI contributes to economic growth only when a sufficient absorptive capability of the advanced technologies is available in the host economy.

Azman-Saini et al. (2010); Mogens (2008); Paakkonen (2010) and Pourshahabi et al. (2011) investigate the systemic link between economic freedom, foreign direct investment and economic growth in a panel of 85 countries. Their empirical results, based on the generalized method-of-moment system estimator, reveal that FDI by itself has no direct (positive) effect on output growth. Instead, the effect of FDI is contingent on the level of economic freedom in the host countries. This means the countries promote greater freedom of economic activities gain significantly from the presence of multinational corporations (MNCs).

Iamsiraroj and Ulubaşoğlu (2015) results that the FDI is positively affect economic growth. And found appropriate absorptive capacity indicators for positive growth are identified to be trade openness and financial development rather than schooling. Alguacil et al. (2011) contribute to the discussion on the role played by the absorptive capacities within host economies in their ability to grow and to exploit FDI efficiently. Alvarado et al. (2017), studies foreign direct investment and economic growth in Latin America and examines the effect of foreign direct investment (FDI) on economic growth in 19 Latin American countries.

By using panel data econometrics, they found that the effect of FDI on economic growth is not statistically significant in aggregated form. And they advance that FDI is not an adequate mechanism to accelerate economic growth in Latin America, with the exception of high-income countries.

The interest of the economic freedom study and its role in raising the volume of foreign direct investment and economic growth is especially in light of the new economic era that supports economic openness and globalization. The Apergis and Arusha (2017) study confirmed that FDI is positively correlated with economic growth in host countries which requires adequate human capital, economic

1 Saudi Arabia, United Arab Emirates, Oman, Qatar, Kuwait and Bahrain. 
stability and market liberalization to capitalize on long-term capital flows. Goel et al. (2017) deals with economic freedom as an indicator of economic freedom. In this study it was ascertained that economic freedom contributes to economic growth. For the study of Azman-Saini et al. (2010), it touched on the investigation of linkages between business environment indicators (e.g., economic freedom) on the one hand, and foreign direct investment and economic growth on the other. The study was based on a sample of 85 countries and showed that countries that are interested in improving the business climate, such as promoting economic freedom, are the beneficiaries rather than the multinational companies. As for Saha et al. (2017) found a causal link between economic freedom and political inbound tourism for more than 110 countries during 1995-2012. In general, most studies confirm the importance and role of economic freedom in attracting foreign direct investment and raising the rate of economic growth. This is why we are concerned about this problem in the GCC (Saudi Arabia, United Arab Emirates, Qatar, Kuwait and Oman).

\section{Empirical Analysis}

\subsection{Data and Methodology}

We study the effect of FDI and economic freedom on economic growth in GCC countries. All papers have dealt with the issue of the relationship FDI/growth. So we take the initiative to address this issue. The second motivation comes from the fact that our target region is a set of countries whose economy is based on oil; and we are witnessing these years a drop in oil prices that has stabilized at \$ 30. This framework uses a standard model consisting of GCC countries (Saudi Arabia, United Arab Emirates, Qatar, Kuwait and Oman) during the period from 1995 to 2017. (2013) will be based on the analytical descriptive approach in the first stage and quantitative analytical approach, which includes the modern standard methods to determine the role of economic freedom in raising foreign direct investment and thus economic growth in the second stage. To study the relationship between economic freedom and the flow of foreign investment and economic growth of the GCC countries, the following standard model will be used:

$$
\operatorname{RGDPD}_{\mathrm{i}, \mathrm{t}}=\beta_{0}+\beta_{1} \mathrm{FDI}_{\mathrm{i}_{\mathrm{i}, \mathrm{t}}}+\beta_{2} \mathrm{FE}_{\mathrm{i}_{\mathrm{i}, \mathrm{t}}}+\beta_{3} \mathrm{OPEN}_{\mathrm{i}_{\mathrm{i}, \mathrm{t}}}+\beta_{4} \mathrm{GSAV}_{\mathrm{i}_{\mathrm{i}, \mathrm{t}}}+\varepsilon_{\mathrm{i}, \mathrm{t}}
$$

RGDPG: Represents the rate of economic growth

FDI: Is the ratio of foreign direct investment

EF: Is the index of economic freedom. Several indicators adopted by the World Bank can also be used.

OPEN: Represents the growth rate of economic openness

GSAV: Represents the gross savings rate.

Data are from model variables are collected from World Bank statistics World Development Indicators database-The Word Bank. The Freedom Economic Index data was collected from Heritage.

This model will be applied to a sample consisting of the GCC countries (Saudi Arabia, United Arab Emirates, Qatar, Kuwait, and Oman).

The empirical strategy is based on two approaches, panel data analysis and system GMM, to check the soundness of the results. The double dimensions, individual (countries) and temporal (years), of our sample oriented us towards the selection of panel data analysis. Panel data generally presents less multicollinearity than time series or cross section data. Also, it leads to more precise coefficient estimations.

Using panel data, the non-stationarity of time series and estimate errors seem to have been reduced (Baltagi 1995, 2001 and Ryan et al. 2011). Also, the GMM method has several advantages. It allows one to solve the problems of simultaneity bias, reverse causality and omitted variables which have weakened the results of previous studies. It also addresses the problem of the endogeneity of explanatory variables (Hansen 1982; Hansen and Singleton 1982; Tan 2015).

Our methodology is to conduct the panel data method over several stages. The first will be to test the effect of Economic Freedom (EF) and FDI on economic growth. At this level, we will use the global index of the EF. In the second step we will try to test the effect of the components of the EF 
(6 components) on economic growth. In the third step, we will test the effect of EF and each component and its interaction with FDI on pattern-based economic growth.

As a result, we will have 7 models. In the fourth step, we will test the effect of EF components and their interactions with FDI on economic growth. At this level, we introduce all the variables together. In the last step, we will present the Results of Panel Fully Modified OLS (PFMOLS) and Dynamic Least Squares (DOLS) regressions.

The validity of the system GMM requires that three conditions be fulfilled. First, the Sargan test of over-identifying restrictions should provide no correlation between instruments and error term.

Second, for the second order correlation, there should be no serial correlation. System GMM results indicate that the Sargan and serial-correlation tests do not reject the null hypothesis of correct specification ( $p$-value of Sargan test and $p$-value of AR(2) test of Arellano and Bond are larger than $5 \%$ ), providing support for our estimation results. The $p$-value of the Sargan test of over-identifying restrictions is equal to $16 \%$ which is higher than $5 \%$. Hence, we confirm the overall validity of the instruments. Also, the $p$-value of $\operatorname{AR}(2)$ is equal to $40.6 \%$ (more than $5 \%$ ) which implies that there is no correlation.

Finally, we check the robustness of our results based from different test of Cointegration: the results of Pedroni Residual Cointegration Test, Kao Residual Cointegration Test and Johansen Fisher panel cointegration test.

\subsection{Results and Interpretation}

\subsubsection{Pre-Estimation: Descriptive Statistics and the Correlation Matrix}

\section{Descriptive Statistics}

Table 1 below summarizes descriptive statistics for our sample. Descriptive statistics are presented to describe the basic characteristics of the data used in this study. For each variable, we have the average value, the standard deviation, the minimum and the maximum values. The results of the descriptive statistics indicate that the average value of economic freedom index is (72.178). From these statistics, for the GDP growth per capita, descriptive statistics show that the average level of growth equal to $(5.767 \%)$ with a minimum value of $(-7.076 \%)$ and a maximum value of $(+28.447 \%)$.

Table 1. Descriptive statistics. RDGPG: Represents the rate of economic growth; EF: Economic Freedom; FDI: foreign direct investment; OPEN: average value of trade openness.

\begin{tabular}{cccccc}
\hline & RGDPG & EF & FDI & OPEN & GDSAV \\
\hline Mean & 5.888 & 45.26 & 4.036 & 105.726 & 36.639 \\
Median & 4.861 & 66.700 & 2.936 & 95.584 & 33.431 \\
Maximum & 28.447 & 69.000 & 33.566 & 164.115 & 69.610 \\
Minimum & -7.076 & 60.400 & -1.315 & 56.474 & 7.342 \\
Std. Dev. & 5.422 & 1507.455 & 5.139 & 25.895 & 15.854 \\
Skewness & 1.521 & 3.674 & 2.853 & 0.311 & 0.401 \\
Observations & 114 & 114 & 114 & 114 & 114 \\
\hline \multicolumn{7}{c}{ RGDPG } & FDI & EF & OPEN & GDSAV \\
\hline RGDPG & 1.000 & & & & \\
FDI & 0.329 & 1.000 & & & \\
EF & 0.146 & -0.076 & 1.000 & & \\
OPEN & -0.091 & -0.207 & 0.567 & 1.000 & \\
GSAV & 0.412 & 0.174 & -0.244 & -0.407 & 1.000 \\
\hline
\end{tabular}

The average level of foreign direct investment net inflow (FDI) remains an average of $3.642 \%$; having a maximum value of $33.566 \%$ while its minimum value is $-1.315 \%$. Contrary to foreign investment, the average value of domestic investment (INVES) seems to be satisfactory with a level of $46.355 \%$; its maximum value is $75 \%$ while its minimum value is $30.000 \%$. For gross domestic savings (GDSAV), the average value is $36.554 \%$; its minimum value is $7.342 \%$ and $69.610 \%$ as its maximum 
value. Descriptive statistics indicate respectable values for trade openness. We find that the average value of trade openness (OPEN) is $105.726 \%$ and the maximum value is $164.115 \%$.

\subsubsection{FDI. Economic Freedom and Economic Growth in GCC Countries}

Table 2 shows that Saudi knew a high rate of growth during the period 1970-1976. The RGDPC growth crossed from $12.03 \%$ in 1970 to reach $19.94 \%$ in 1971 and $12.72 \%$ in 1976 . While the FDI inflow recorded negative values for the same period. FDI in \% of PIB take a value of $-1.64 \%$ in 1971 and -8.3 in 1974. The divergence trend of those indicators indicates that FDI did not well contribute to the growth of Saudi Arabia during this period. This country allows more importance to the oil revenue which is considered as the engine of growth.

Table 2. Economic Freedom and Economic Growth in Gulf Cooperation Council (GCC) countries.

\begin{tabular}{cccc}
\hline Years & Index of Economic Freedom & FDI Inflow (in \% of GDP) & Real GDP Growth (\%) \\
\hline 1995 & 68.64 & 1.338 & 4.25 \\
1996 & 69.02 & 6.388 & 3.93 \\
1997 & 70.04 & 2.679 & 8.01 \\
1998 & 68.52 & 2.286 & 3.93 \\
1999 & 69.27 & 1.382 & 2.26 \\
2000 & 68.25 & 2.464 & 6.82 \\
2001 & 68.00 & 1.078 & 2.29 \\
2002 & 68.47 & 1.289 & 3.68 \\
2003 & 66.48 & 2.616 & 8.01 \\
2004 & 65.70 & 4.208 & 10.62 \\
2005 & 64.90 & 6.327 & 7.43 \\
2006 & 64.75 & 9.297 & 10.62 \\
2007 & 65.28 & 6.792 & 8.27 \\
2008 & 66.77 & 5.843 & 7.54 \\
2009 & 68.42 & 5.113 & 1.65 \\
2010 & 69.33 & 3.189 & 5.02 \\
2011 & 68.45 & 2.402 & 6.37 \\
2012 & 68.67 & 2.277 & 4.16 \\
2013 & 68.57 & 2.230 & 4.75 \\
2014 & 69.33 & 3.189 & 5.02 \\
2015 & 68.45 & 2.402 & 6.37 \\
2016 & 68.25 & 2.464 & 6.82 \\
2017 & 69.27 & 1.382 & 2.26 \\
\hline
\end{tabular}

Source: Data related to economic Freedom are collected from www.heritage.org/index/ranking. Data related to FDI and Economic growth are collected from the World Bank Indicators.

Since 1977, the FDI net inflows begin to know positive values. Those positive values coincide with the development plan for 1975-1979 to encourage foreign direct investment. For example, we record a value of FDI of 1.06\% in 1977. GDPpc growth continues to have positive value during the period 1977-1981 with respectively values of $7 \%$ and $4.69 \%$. Since 1982, Saudi Arabia recorded negative rate of GDPpc growth. Those rates reach $-11.1 \%$ in 1982 and $-8.22 \%$ in 1983 . GDPpc gets back to its positive values from 1988 and its fluctuations appear almost stable during the remaining period. Also, the FDI curve is constant during the period 1986-2004. However, it records very low values. Since 2005, the FDI net inflow follows a rising trend. It's crossed from $3.84 \%$ in 2005 to reach $9.68 \%$ in 2009.

\subsubsection{Results of Correlation Matrix}

The results of the matrix correlation in Table 3 demonstrate a strong correlation between the components of GDP and trade openness and the components of economic. The economic development literature has shown that industry adds to services, while the opposite is also true. The levels of correlation are $0.992,0.518$, and 0.502 for those pairs, respectively. There is also a strong negative correlation between the value added components of economic freedom and FDI. Also, a negative correlation between the values added components of economic freedom and the savings rate. 
Table 3. Correlation Matrix.

\begin{tabular}{|c|c|c|c|c|c|c|c|c|c|c|c|c|c|c|c|c|c|}
\hline & RGDPG & FDI & Gfc & OPEN & GDSAV & Fisf & Busf & Monf & Tradf & Invesf & Finanf & Fisfxfdi & Busfxfdi & Monfxfdi & Tradfxfdi & Invesfxfdi & Finafxfdi \\
\hline RDGPG & 1 & & & & & & & & & & & & & & & & \\
\hline FDI & 0.147 & 1 & & & & & & & & & & & & & & & \\
\hline Gfc & -0.203 & 0.119 & 1 & & & & & & & & & & & & & & \\
\hline OPEN & -0.093 & 0.53 & -0.081 & 1 & & & & & & & & & & & & & \\
\hline GDSAV & 0.414 & -0.239 & -0.097 & -0.4 & 1 & & & & & & & & & & & & \\
\hline fisf & 0.024 & -0.163 & 0.257 & -0.197 & 0.234 & 1 & & & & & & & & & & & \\
\hline busf & -0.212 & -0.005 & 0.032 & 0.078 & -0.361 & 0.235 & 1 & & & & & & & & & & \\
\hline monf & -0.013 & 0.15 & 0.027 & 0.109 & -0.303 & -0.103 & 0.147 & 1 & & & & & & & & & \\
\hline tradf & 0.043 & -0.086 & -0.002 & 0.158 & 0.308 & 0.56 & 0.071 & -0.444 & 1 & & & & & & & & \\
\hline invesf & -0.138 & 0.22 & -0.306 & 0.37 & -0.344 & -0.557 & 0.001 & -0.001 & -0.171 & 1 & & & & & & & \\
\hline finanf & -0.091 & 0.329 & -0.162 & 0.58 & -0.422 & -0.249 & 0.414 & 0.146 & -0.08 & 0.57 & 1 & & & & & & \\
\hline fisfxfdi & 0.152 & 0.991 & 0.147 & 0.518 & -0.212 & -0.089 & 0.034 & 0.133 & -0.026 & 0.184 & 0.316 & 1 & & & & & \\
\hline busfxfdi & 0.095 & 0.964 & 0.113 & 0.502 & -0.252 & -0.093 & 0.164 & 0.162 & -0.045 & 0.216 & 0.354 & 0.976 & 1 & & & & \\
\hline monfxfdi & 0.134 & 0.997 & 0.137 & 0.526 & -0.259 & -0.16 & 0.013 & 0.199 & -0.099 & 0.221 & 0.335 & 0.989 & 0.969 & 1 & & & \\
\hline tradfxfdi & 0.148 & 0.992 & 0.148 & 0.521 & -0.226 & -0.108 & 0.015 & 0.116 & 0.001 & 0.198 & 0.309 & 0.996 & 0.972 & 0.987 & 1 & & \\
\hline invesfxfdi & 0.092 & 0.971 & 0.068 & 0.541 & -0.334 & -0.247 & 0.03 & 0.173 & -0.143 & 0.377 & 0.413 & 0.946 & 0.938 & 0.973 & 0.953 & 1 & \\
\hline finafxfdi & 0.104 & 0.975 & 0.095 & 0.551 & -0.285 & -0.166 & 0.092 & 0.194 & -0.113 & 0.275 & 0.461 & 0.966 & 0.959 & 0.975 & 0.961 & 0.971 & 1 \\
\hline
\end{tabular}

Where: RGDPG: Represents the rate of economic growth. FDI: Is the ratio of foreign direct investment and (Fisfxfdi, Busfxfdi, Monfxfdi, Tradfxfdi, Invesfxfdi and Finafxfdi) are the components of the FDI. EF: Is the index of economic freedom. Fisf, Busf, Monf, Tradf, Invesf and Finanf: Represents the components of the EF. OPEN: Represents the growth rate of economic openness. GSAV: Represents the Gross savings rate. Gfc: Represents the domestic investment. 


\subsection{Results of the Effect of Economic Freedom and FDI on Economic Growth}

The results of the Effect of Economic Freedom (EF) and FDI (FDI) on economic growth (EG) are summarized in Table 4. The results showed that all the coefficients are positive except economic freedom and trade openness with a negative coefficient respectively equal $(-0.263)$ and $(-0.025)$.

Thereafter, we note that the coefficients of economic freedom and savings rate are statically significant. With a positive coefficient for the savings rate equal (0.176).

Results indicate that the effect of Effect of EF and FDI on economic growth (EG) is solid since its coefficient is negative and statistically significant at the 1\% level for Economic Freedom and trade openness. Coefficients of FDI and savings rate are respectively positive and statistically significant.

Table 4. The effect of economic freedom (EF) and FDI on economic growth (EG).

\begin{tabular}{ccccc}
\hline Rgdpg & Coef. & Std. Err. & $\mathbf{t}$ & $\boldsymbol{p}>\mathbf{t}$ \\
\hline Ef & -0.263 & 0.157 & -1.67 & $0.098^{* *}$ \\
Fdi & 0.200 & 0.118 & 1.70 & $0.092^{* *}$ \\
Gfc & 0.073 & 0.104 & 0.70 & 0.484 \\
Gsav & 0.176 & 0.032 & 5.50 & $0.000^{* * *}$ \\
Open & -0.025 & 0.042 & -0.60 & 0.550 \\
_cons & 23.621 & 11.758 & 2.01 & $0.047^{* *}$ \\
\hline chi2 haus & 14.200 & - & - & - \\
Prob & 0.006 & - & - & - \\
Fisher & 2.030 & - & - & - \\
Prob $>$ F & 0.097 & - & - & - \\
$\mathrm{N}^{\circ}$ Obs & 104 & - & - & - \\
\hline ** and ${ }^{* * *}$ denote level of significance respectively at $5 \%$ and $1 \%$.
\end{tabular}

\subsection{Results of the Effect of the Components of the EF (6 Components) on Economic Growth}

We introduce the interactive relation between the components of the economic freedom with six components and economic growth in Table 5. Thus, the coefficient savings rate is more significant in spite of its positive sign. The coefficient trade openness is negative and statistically insignificant suggesting that the effects of economic freedom on economic growth are more apparent with a higher level of investment. This may be explained by a negative coefficient and significant of investment with a coefficient equal $(-0.151)$, and with a positive and significant coefficient for the variable Gross save rating equal (0.176).

Table 5. Effect of the components of the EF (6 components) on EG.

\begin{tabular}{ccccc}
\hline RGDPG & Coef. & Std. Err. & $\mathbf{t}$ & $p>\mathbf{t}$ \\
\hline FDI & 0.140 & 0.118 & 1.180 & 0.240 \\
Gfc & 0.081 & 0.106 & 0.760 & 0.448 \\
OPEN & -0.084 & 0.052 & -1.610 & 0.111 \\
Gsav & 0.175 & 0.059 & 2.960 & $0.004^{* * *}$ \\
Ef & -0.263 & 0.188 & -1.400 & 0.166 \\
Fisf & 0.044 & 0.079 & 0.560 & 0.574 \\
Busf & 0.066 & 0.062 & 1.070 & 0.289 \\
Monf & 0.039 & 0.084 & 0.460 & 0.648 \\
Tradf & 0.013 & 0.092 & 0.140 & 0.891 \\
Invesf & -0.151 & 0.062 & -2.440 & $0.017 * *$ \\
Finanf & 0.001 & 0.074 & 0.010 & 0.993 \\
_cons & 17.611 & 19.156 & 0.920 & 0.361 \\
\hline chi2 haus & 41.39 & - & - & - \\
Prob & 0.000 & - & - & - \\
Fisher & 2.17 & - & - & - \\
Prob $>$ F & 0.0248 & - & - & - \\
$\mathrm{N}^{\circ}$ Obs & 93 & - & - & - \\
\hline
\end{tabular}

** and ${ }^{* * *}$ denote level of significance respectively at $5 \%$ and $1 \%$. 


\subsection{Result of Panel Data Analysis on the Effect of Economic Freedom and FDI on the Economic Growth}

We estimate regressions by including all the variables with all the components. The Coefficient EF and Trade openness are negative and insignificant. Results present in Table 6, coefficient (Invesf) is negative and significant, and one unit increase of the index decreases growth by $1.51 \%$. The results devote a negative and significant correlation between economic freedom and foreign direct investment (FDI), also, we note a positive correlation between FDI and trade openness with a coefficient equal (0.433).

More concretely, access to credit leads to more investment which turns positively on the level of growth (Rajan and Zingales 1998; Guiso et al. 2004). However, our results have revealed negative relationships. These results indicate that the governments of GCC countries should adopt a more flexible but prudent credit policy to stimulate investment, especially in the private sector as an important key to boosting economic growth in this region. It's obvious that foreign direct investment (FDI) is an important factor in stimulating economic growth. Results of system GMM show a positive and significant association between FDI and GDPPC.

This finding supports the positive role of FDI as a channel of technological transfer and a factor for promoting employment and improving the productivity of local firms. However, these results are only significant at $10 \%$ and the coefficient is very weak at only $3.8 \%$. This implies that GCC countries should put more effort into financial reform, business environment and fighting corruption to attract more foreign investment. It is better for foreign investment to be cleaner to protect the environment and more productive to absorb the high rate of unemployment. The positive association between FDI and GDPPC is in line with the findings of Sayari et al. (2018) and Borensztein et al. (1998). Like foreign direct investment, domestic investment (INVES) is recognized as an important key for economic growth. Domestic direct investment (DDI) is considered as a smarter capital. In China for example, DDI represents $40 \%$ of all investments. However, FDI is only about 3\%. Our empirical findings indicate that there is a highly positive and significant association between domestic investment and economic growth. 
Table 6. Result of Panel Data Analysis on the effect of Economic Freedom and FDI on the Economic Growth.

\begin{tabular}{|c|c|c|c|c|c|c|c|c|c|c|c|c|c|c|}
\hline & $\mathrm{EF}$ & & FISF & & BUS & & MONF & & TRADF & & INVESF & & FINANF & \\
\hline RGDPG & Coeff & Z-Stat & Coeff & Z-Stat & Coeff & Z-Stat & Coeff & Z-Stat & Coeff & Z-Stat & Coeff & Z-Stat & Coeff & Z-Stat \\
\hline FDI & -0.008 & -1.000 & 1.005 & 1.290 & 1.057 & $2.250 * *$ & 4.330 & $3.110 * * *$ & 0.433 & 0.490 & -0.186 & -0.360 & 0.082 & $2.660 * * *$ \\
\hline Gfc & 0.000 & 0.110 & -0.102 & -1.510 & 0.003 & 0.020 & -0.118 & -1.930 & -0.091 & -1.410 & 0.076 & 0.760 & -0.108 & -1.700 \\
\hline OPEN & 0.001 & 0.310 & -0.010 & -0.410 & -0.033 & -0.700 & -0.004 & -0.180 & -0.007 & -0.300 & -0.090 & -1.910 & -0.030 & -1.130 \\
\hline Gsav & -0.003 & -1.230 & 0.160 & $4.910^{* * *}$ & 0.137 & $2.710^{* * *}$ & 0.170 & $5.440 * * *$ & 0.163 & $4.660^{* * *}$ & 0.191 & $3.560 * * *$ & 0.157 & $4.960^{* * *}$ \\
\hline Ef & -0.085 & $-11.650^{* * *}$ & & & & & & & & & & & & \\
\hline Efxfdi & 0.015 & $155.500^{* * *}$ & & & & & & & & & & & & \\
\hline Fisf & & & 0.018 & 0.350 & & & & & & & & & & \\
\hline Fisfxfdi & & & -0.008 & -0.890 & & & & & & & & & & \\
\hline $\begin{array}{l}\text { Busf } \\
\text { busfxfdi }\end{array}$ & & & & & $\begin{array}{c}0.074 \\
-0.010\end{array}$ & $\begin{array}{c}1.140 \\
-1.830\end{array}$ & & & & & & & & \\
\hline Monf & & & & & 0.010 & & 0.256 & $2.840 * * *$ & & & & & & \\
\hline monfxfdi & & & & & & & -0.048 & $-2.900 * * *$ & & & & & & \\
\hline Tradf & & & & & & & & & -0.034 & -0.440 & & & & \\
\hline tradfxfdi & & & & & & & & & -0.002 & -0.150 & & & & \\
\hline Invesf & & & & & & & & & & & -0.186 & $-2.790^{* * *}$ & & \\
\hline invesfxfdi & & & & & & & & & & & 0.008 & 0.720 & & \\
\hline Finanf & & & & & & & & & & & & & 0.082 & 1.660 \\
\hline finanfxfdi & & & & & & & & & & & & & -0.016 & $-2.100^{* * *}$ \\
\hline _cons & 5.663 & $11.21^{* * *}$ & 0.409 & 0.07 & -2.443 & -0.33 & -19.251 & $-2.29 * *$ & 4.048 & 0.75 & 14.454 & $2.57^{* * *}$ & -0.452 & -0.11 \\
\hline chi2 haus & 6.280 & & 11.630 & & 12.700 & & 6.440 & & 9.140 & & 31.710 & & 6.300 & \\
\hline Prob & 0.393 & & 0.070 & & 0.048 & & 0.375 & & 0.165 & & 0.000 & & 0.390 & \\
\hline wald chi2 & 34.007 & & 37.600 & & - & & 50.290 & & 37.160 & & - & & 42.890 & \\
\hline Prob $>$ chi2 2 & 0.000 & & 0.000 & & - & & 0.000 & & 0.000 & & - & & 0.000 & \\
\hline Fisher & - & & - & & 2.630 & & - & & - & & 3.650 & & - & \\
\hline $\mathrm{N}^{\circ}$ Obs & 99 & & 92 & & 92 & & 92 & & 92 & & 92 & & 92 & \\
\hline
\end{tabular}

${ }^{* *}$ and ${ }^{* * *}$ denote level of significance respectively at $5 \%$ and $1 \%$. 


\subsection{Effect of EF Components and Their Interactions with FDI on Economic Growth (EG)}

From the results of the effect of EF components and their interactions with FDI on economic growth (EG) presented in Table 7, we remark that the components of the variable Economic Freedom exert a positive relation on the variable (FDI) with a positive coefficient (2.856), this positive correlation is stronger than the other correlation such as the correlation with savings rates $(0.181)$.

Furthermore, the results shown in the table below show a very good whole model fit as remarked by the Wald chi-Square (34.007) and Hausman chi-Square respectively (6.280).

Table 7. Effect of EF components and their interactions with FDI on economic growth (EG).

\begin{tabular}{lcccc}
\hline RGDPG & Coef. & Std. Err. & $\mathbf{z}$ & $p>\mathbf{z}$ \\
\hline FDI & 2.856 & 3.328 & 0.860 & 0.391 \\
gfc & -0.155 & 0.072 & -2.140 & $0.0322^{* *}$ \\
OPEN & -0.012 & 0.034 & -0.330 & 0.738 \\
gsav & 0.181 & 0.046 & 3.920 & $0.000 * * *$ \\
fisf & 0.002 & 0.081 & 0.020 & 0.984 \\
busf & 0.049 & 0.080 & 0.620 & 0.538 \\
monf & 0.166 & 0.122 & 1.360 & 0.173 \\
tradf & -0.050 & 0.125 & -0.400 & 0.690 \\
invesf & -0.055 & 0.064 & -0.850 & 0.393 \\
finanf & 0.077 & 0.065 & 1.180 & 0.236 \\
fisfxfdi & 0.004 & 0.022 & 0.160 & 0.870 \\
busfxfdi & -0.009 & 0.012 & -0.710 & 0.478 \\
monfxfdi & -0.021 & 0.026 & -0.810 & 0.419 \\
tradfxfdi & 0.004 & 0.022 & 0.190 & 0.847 \\
invesfxfdi & 0.005 & 0.017 & 0.280 & 0.781 \\
finafxfdi & -0.014 & 0.010 & -1.430 & 0.154 \\
_cons & -13.006 & 13.899 & -0.940 & 0.349 \\
\hline chi2 haus & 6.280 & & & \\
prob & 0.393 & & & \\
wald chi2 & 34.007 & & & \\
Prob > chi2 & 0.000 & & & \\
$\mathrm{~N}^{\circ}$ Obs & 99 & & \\
\hline ** and *** denote level of significance respectively at $5 \%$ and $1 \%$.
\end{tabular}

\subsection{Panel Unit Root Test (PURT) and Panel Cointegration}

We use the Augmented Dickey-Fuller (F-ADF) unit root tests to check the stationarity of each variable. The augmented Dickey-Fuller (ADF) statistic, used in the test, is a negative number. The more negative, it is, the stronger the rejection of the hypothesis that there is a unit roots. The results of the Augmented Dickey-Fuller (ADF) and Phillips-Perron (PP) tests for the four variables of the model are presented in Table 8.

Table 8. Results of Panel Unit Root Test (PURT).

\begin{tabular}{|c|c|c|c|c|c|c|c|c|c|c|c|}
\hline \multirow{2}{*}{ Method } & \multicolumn{2}{|c|}{ RGDPG } & \multicolumn{2}{|c|}{ FDI } & \multicolumn{2}{|r|}{$\mathrm{EF}$} & \multicolumn{2}{|c|}{ OPEN } & \multicolumn{2}{|c|}{ GSAV } & \multirow{2}{*}{ Order of Integration } \\
\hline & LEVEL & FIRST & LEVEL & FIRST & LEVEL & FIRST & LEVEL & FIRST & LEVEL & FIRST & \\
\hline LLC & -0.194 & $-3.946^{* * *}$ & 0.7978 & $-2.523 * * *$ & -1.272 & $-2.237^{* *}$ & -1.191 & $-5.469 * * *$ & -1.234 & $-3.059 * * *$ & $\mathrm{I}(1)$ \\
\hline Breitung & -0.1846 & $-3.169 * * *$ & -1.412 & $-2.714^{* * *}$ & -0.247 & $-4.25 * * *$ & -1.539 & $-5.032 * * *$ & -1.312 & $-4.307 * * *$ & $\mathrm{I}(1)$ \\
\hline ADF & 11.0234 & $36.229^{* * *}$ & 15.979 & $24.575^{* *}$ & 13.91 & $25.735^{* *}$ & 17.75 & $30.405^{* * *}$ & 10.922 & $23.795 * *$ & I(1) \\
\hline PP & 16.3737 & $90.139 * * *$ & 18.658 & $54.88^{* * *}$ & 10.46 & $70.429 * * *$ & 10.913 & $51.978 * * *$ & 7.6922 & $53.781^{* * * *}$ & $\mathrm{I}(1)$ \\
\hline
\end{tabular}

The results show that in the level, the null hypothesis cannot be rejected for all the variables for both the two-unit root test ADF and Phillips-Perron (PP) test. GDPPC, FDI, OPEN, EF, and GSAV are not stationary in the level. By testing through first difference, the results rejected the null hypothesis of non-stationarity. The unit roots tests confirm that each variable is integrated of order one. 
Findings of the cointegration tests indicate that there exist relationships between variables. Therefore, all the variables are cointegrated.

\subsection{Result of Panel Fully Modified OLS (PFMOLS) and Dynamic Least Squares (DOLS)}

Two statistics are used in the cointegration test of Johansen (1988), they are Trace test and Max-Eigen value. The cointegration test aims to check whether it exist a long run relationship association.

Table 9 below presents the result of long-run association reveals that FDI acts positively and significantly on the economic growth. Although that the FDI in GCC countries transmitted by the multinational corporation have several welfare advantages, one of which is the technology transfer. FDI promotes economic growth by stimulating technological progress, which affect positively the economic growth (Borensztein et al. 1998). Foreign firms transfer new products or processes to the domestic market, domestic firms may benefit from the accelerated diffusion of new technology (Teece 1977). To fight the competition of foreign company, domestic firms try to increase their economic freedom. An increase of economic freedom can stimulate the growth economic. The trade openness acts positively and significantly on the economic growth and economic freedom. Also trade openness promotes the efficient allocation of resources through comparative advantage, allows the dissemination of knowledge and technological progress, and encourages competition in domestic and international markets. Our finding is consistent with the studies of Romer (1993); Grossman and Helpman (1991).

Table 9. Result of Panel Fully Modified Ordinary Least Square (FMOLS), Dynamic Least Squares (DOLS) Regression.

\begin{tabular}{|c|c|c|c|c|c|c|c|c|}
\hline \multirow[b]{2}{*}{ RGDPG } & \multicolumn{4}{|c|}{ FMOLS } & \multicolumn{4}{|c|}{ DOLS } \\
\hline & Coeff & Std. Err & t-Stat & Prob. & Coeff & Std. Err & t-Stat & Prob. \\
\hline FDI & 0.001 & 0.000 & 2.014 & $0.047 * *$ & 0.006 & 0.001 & 4.797 & $0.000 * * *$ \\
\hline EF & 0.371 & 0.128 & 2.890 & $0.004^{* * *}$ & -0.537 & 0.396 & -1.356 & 0.187 \\
\hline OPEN & -0.066 & 0.051 & -1.300 & 0.197 & 0.256 & 0.097 & 2.653 & $0.013^{* *}$ \\
\hline GSAV & 0.110 & 0.053 & 2.075 & $0.041^{* *}$ & -0.198 & 0.064 & -3.100 & $0.005^{* * *}$ \\
\hline $\mathrm{R} 2$ & \multicolumn{4}{|c|}{0.385} & \multicolumn{4}{|c|}{0.977} \\
\hline Adjusted R2 & \multicolumn{4}{|c|}{0.318} & \multicolumn{4}{|c|}{0.918} \\
\hline Durbin-Watson & \multicolumn{4}{|c|}{1.759} & \multicolumn{4}{|c|}{-} \\
\hline \multicolumn{9}{|c|}{ Diagnostic tests } \\
\hline Q-Stat & \multicolumn{4}{|c|}{0.681} & \multicolumn{4}{|c|}{3.415} \\
\hline Prob & \multicolumn{4}{|c|}{0.711} & \multicolumn{4}{|c|}{0.065} \\
\hline Squared Res & \multicolumn{4}{|c|}{3.556} & \multicolumn{4}{|c|}{13.405} \\
\hline Prob & \multicolumn{4}{|c|}{0.168} & \multicolumn{4}{|c|}{0.000} \\
\hline
\end{tabular}

The results suggest the existence of the long-run cointegrating relationship between economic freedom and economic growth that is statistically significant. It is approximately 0.371 , meaning that, on average, a $1 \%$ change in GDP leads to a $0.371 \%$ change in economic freedom. Also positive relation between trade openness and economic growth, meaning that, on average, a $1 \%$ change in GDP leads to a $0.256 \%$ change in trade openness. The close values of long-run coefficients for all estimations confirm the robustness of the estimated results.

\section{Robustness Tests Check}

Lu and White (2014) study when and how one can infer structural validity from coefficient robustness and plausibility. And provide a straightforward new Hausman (1978) type test of robustness for the critical core coefficients, additional diagnostics that can help explain why robustness test rejection occurs, and a new estimator, the Feasible Optimally combined GLS (FOGLeSs) estimator, that makes relatively efficient use of the robustness check regressions. 
The robustness tests tried to examine how certain "core" regression coefficient estimates behave when the regression specification is modified by adding or removing regressors. If the coefficients are plausible and robust, this is commonly interpreted as evidence of structural validity.

To check the model specification, or how robust the coefficients of economic freedom, FDI, Growth economic, trade openness and save ratings are to changes in the conditioning set of information, we apply the extreme bound analysis (Levine and Renelt 1992).

Robustness checks showed consistent results estimating the model with standard errors. For the Panel Fully Modified OLS (PFMOLS) and Dynamic Least Squares (DOLS) model, we also estimated standard errors.

Table 10 below summarizes the results from different test of Cointegration: the results of Pedroni Residual Cointegration Test, Kao Residual Cointegration Test and Johansen Fisher panel cointegration test.

We provide the results of seven panel cointegration tests suggested by Pedroni $(1999,2004)$ between dimensions are reported in Table 10. These seven tests are based on the estimated residuals.

The test results indicate that most statistics are statistically significant, and therefore the null hypothesis of no cointegration can be rejected at conventional levels, suggesting that the variables are cointegrated in both models. For the results of panel cointegration test, suggested by Kao (1999). The test results also indicate that variables between dimensions are panel cointegrated with $5 \%$ and $1 \%$ significance levels, respectively.

Finally, the results of panel cointegration test suggested Johansen Fisher panel cointegration test indicate that with the asymptotic $p$-values, the no cointegration null is rejected.

Table 10. Results of different test of Cointegration.

\begin{tabular}{|c|c|c|c|c|c|}
\hline \multicolumn{6}{|c|}{ Pedroni Residual Cointegration Test } \\
\hline & & \multicolumn{4}{|c|}{ Weighted } \\
\hline & & Statistic & Prob. & Statistic & Prob. \\
\hline Panel v-Statistic & & -1.704 & 0.955 & -1.857 & 0.968 \\
\hline Panel rho-Statist & & -0.406 & 0.342 & -0.285 & 0.387 \\
\hline Panel PP-Statisti & & -6.621 & $0.000^{* * *}$ & -6.387 & $0.000 * * *$ \\
\hline Panel ADF-Stati & & -2.048 & $0.020^{* *}$ & -2.665 & $0.003^{* *}$ \\
\hline \multicolumn{6}{|c|}{ Alternative hypothesis: individual AR coefs. (between-dimension) } \\
\hline & & Statistic & Prob. & & \\
\hline Group rho-Statis & & 1.287 & 0.901 & & \\
\hline Group PP-Statis & & -6.548 & $0.000^{* * *}$ & & \\
\hline Group ADF-Stat & tic & -1.739 & $0.041^{* *}$ & & \\
\hline \multicolumn{6}{|c|}{ Kao Residual Cointegration Test } \\
\hline & $\mathrm{ADF}$ & & $\begin{array}{c}\mathrm{t} \text {-Statistic } \\
-4.650\end{array}$ & $\begin{array}{l}\text { Prob. } \\
0.000^{* * *}\end{array}$ & \\
\hline \multicolumn{6}{|c|}{ Johansen Fisher panel cointegration test } \\
\hline $\begin{array}{l}\text { Hypothesized } \\
\text { No. of CE(s) }\end{array}$ & $\begin{array}{l}\text { Fisher Stat. } \\
\text { (from trace test) }\end{array}$ & Prob. & $\begin{array}{c}\text { Fisher Stat. }{ }^{*} \\
\text { (from max-eigen test) }\end{array}$ & Prob. & \\
\hline None & 160.2 & $0.000^{* * *}$ & 126.2 & $0.000^{* * *}$ & \\
\hline At most 1 & 79.06 & $0.000 * * *$ & 49.24 & $0.000 * * *$ & \\
\hline At most 2 & 40.92 & $0.000^{* * *}$ & 33.26 & $0.000^{* * *}$ & \\
\hline At most 3 & 16.48 & $0.036^{* *}$ & 11.99 & 0.151 & \\
\hline At most 4 & 14.84 & 0.062 & 14.84 & 0.062 & \\
\hline
\end{tabular}

\section{Conclusions and Policy Remarks}

This paper investigated the relationship between economic freedom, FDI and economic growth for a panel of GCC countries for the period 1995-2017. 
We investigate the impact of economic freedom on economic growth and foreign direct investment (FDI). Our findings show a positive and significant relation between economic freedom and FDI and between economic freedoms an economic growth.

Theoretically there is a widespread belief that FDI generates positive externalities for host countries. To explore the linkage between FDI, economic freedom and growth, we had used a dataset related to GCC countries during the period 1995-2017. Data used in this paper are collected from the World Development Indicators (WDI) and for the Freedom Economic Index; the data was collected from the web site Heritage. The empirical approach used in this paper is based on three steps. The first one checks the stationarity of each variable. The second step, aimed to test the existence of a long-run cointegration between variables. This is performed by the Johansen methods. Thirdly, of Panel Fully Modified OLS (PFMOLS) and Dynamic Least Squares (DOLS) is used if all variables are integrated of order one I (1) and cointegrated.

Empirical results show that in long-run regression, FDI promotes economic growth in GCC countries. Also the long-run cointegrating relationship shows that there is a relation between FDI and growth and economic freedom. Findings indicate also that trade openness (LOPEN).

These results are confirming the results of Bengoa and Sanchez-Robles (2003); Azman-Saini et al. (2010) and Goel et al. (2017).

In fact, Bengoa and Sanchez-Robles (2003) found a significant and a positive relation between freedom, foreign direct investment (FDI) and economic growth in 18 countries for 1970-1999. In this context Goel et al. (2017) provide empirically that economic freedom contributes to economic growth. As far as study of Azman-Saini et al. (2010), they found a relation between economic freedom and foreign direct investment and economic growth on the other.

Finally, we perform a robustness tests check for our methodology, we used in this step the results of seven panel cointegration tests suggested by Pedroni $(1999,2004)$ between dimensions.

The results confirm that all variables are statistically significant, and therefore the null hypothesis of no cointegration can be rejected at conventional levels. The same results for the test proposed by Kao (1999).

This finding may be considered of great interest, the GCC countries should continue its efforts to attract foreign investors and to promote FDI by offering many investments incentives by promoting the economic freedom. Also, the GCC countries should encourage and support the FDI by developing the trade openness (LOPEN), which appears an important engine to stimulate the economic growth.

Author Contributions: The research problem was identified by H.D.; the Data Collection was fixed out by L.B.D.; the econometric model was performed by H.D.; both authors contributed to the specification of models and the interpretation of results; the paper was written and supervised by H.D. with collaboration from L.B.D.

Funding: This project was funded by deanship of Scientific Research, Northern Border University for their financial support under grant $\mathrm{N}^{\mathrm{O}}$. (435/000). We are thankful to technical and financial support of the DSR who provided expertise that greatly assisted the research, and my completion of this project could not have been accomplished without him support.

Acknowledgments: We are grateful to two anonymous referees for their helpful suggestion. We are responsible for any remaining errors.

Conflicts of Interest: The authors declare no conflict of interest.

\section{References}

Adams, Samuel. 2009. Foreign direct investment, domestic investment, and economic growth in Sub-Saharan Africa. Journal of Policy Modeling 31: 939-49. [CrossRef]

Ahmad, Najid, Liangsheng Du, Jiye Lu, Jianlin Wang, Hong-Zhou Li, and Muhammad Zaffar Hashmi. 2017. Modelling the $\mathrm{CO}_{2}$ emissions and economic growth in Croatia: Is there any environmental Kuznets curve? Energy 123: 164-72. [CrossRef]

Al Khathlan, Khalid. 2013. Foreign direct investment inflows and economic growth in Saudi Arabia: A co-integration analysis. Review of Economics and Finance 4: 70-80. 
Alguacil, Maite, Ana Cuadros, and Vicente Orts. 2011. Inward FDI and growth: The role of macroeconomic and institutional environment. Journal of Policy Modeling 33: 481-96. [CrossRef]

Almfraji, Mohammad Amin, and Mahmoud Khalid Almsafir. 2014. Foreign Direct Investment and Economic Growth Literature Review from 1994 to 2012. Procedia Social and Behavioral Sciences 129: 206-13. [CrossRef]

Alvarado, Rafael, Maria Iñiguez, and Pablo Ponce. 2017. Foreign direct investment and economic growth in Latin America. Economic Analysis and Policy 56: 176-87. [CrossRef]

Anwar, Sajid, and Lan Phi Nguyen. 2014. Is foreign direct investment productive? A case study of the regions of Vietnam. Journal of Business Research 67: 1376-87. [CrossRef]

Apergis, Nicolas, and Cooray Arusha. 2017. Economic Freedom and Income Inequality: Evidence from a Panel of Global Economies-A Linear and a Non-Linear Long-Run Analysis. The Manchester School 85: 88-105. [CrossRef]

Aurangzeb, Zeb, and Stengos Thanasis. 2014. The role of Foreign Direct Investment (FDI) in a dualistic growth framework: A smooth coefficient semi-parametric approach. Borsa Istanbul Review 14: 133-44. [CrossRef]

Azman-Saini, W. N. W., Ahmad Zubaidi Baharumshah, and Siong Hook Law. 2010. Foreign direct investment. Economic freedom and economic growth: International evidence. Economic Modelling 27: 1079-89. [CrossRef]

Baltagi, Badi H. 1995. Editor's introduction: Panel data. Journal of Econometrics 68: 1-4. [CrossRef]

Baltagi, Badi H. 2001. Econometric Analysis of Panel Data, 2nd ed. New York: John Wiley and Sons.

Becker, Gary S., Kevin M. Murphy, and Robert Tamura. 1990. Human capital, fertility and growth. Journal of Political Economy 98: S12-37. [CrossRef]

Belloumi, Mounir. 2014. The relationship between trade, FDI and economic growth in Tunisia: An application of the autoregressive distributed lag model. Economic Systems 38: 269-87. [CrossRef]

Bengoa, Marta, and Blanca Sanchez-Robles. 2003. Foreign direct investment. Economic freedom and growth: New evidence from Latin America. European Journal of Political Economy 19: 529-45. [CrossRef]

Borensztein, Eduardo R., José R. De Gregorio, and Jongwha Lee. 1998. How does foreign direct investment affect economic growth? Journal of International Economics 45: 115-35. [CrossRef]

Chen, Jen-Eem, and Azreen Mohd Zulkifli. 2012. Malaysian Outward FDI and Economic Growth. Procedia Social and Behavioral Sciences 65: 717-22. [CrossRef]

de Haan, Jakob, and Jan-Egbert Sturm. 2000. On the relationship between economic freedom and economic growth. European Journal of Political Economy 16: 215-41. [CrossRef]

Doucouliagos, Chris, and Mehmet Ali Ulubasoglu. 2006. Foreign direct investment. Economic freedom and economic growth: International evidence. European Journal of Political Economy 22: 60-81. [CrossRef]

Girma, Sourafel. 2005. Absorptive Capacity and Productivity Spillovers from FDI: A Threshold Regression Analysis. Oxford Bulletin of Economics and Statistics 67: 281-306. [CrossRef]

Goel, Rajeev K., James W. Saunoris, and Friedrich Schneider. 2017. Growth in the shadows: Effect of the shadow economy on US economic growth over more than a century. Contemporary Economic Policy. [CrossRef]

Grossman, Gene, and Elhanan Helpman. 1991. Trade, knowledge spillovers, and growth. European Economic Review 35: 517-26. [CrossRef]

Guiso, Luigi, Sapienza Paola, and Zingales Luigi. 2004. Does Local Financial Development Matter? Quarterly Journal of Economics 119: 929-69. [CrossRef]

Gwartney, James. 2004. Ten Consequences of Economic Freedom. NCPA Policy Report No. 268. Dallas: NCPA Policy. ISBN \#1-56808-137-5.

Hamdi, Helmi, Abdelaziz Hakimi, and Sbia Rashid. 2013a. Multivariate Granger Causality between Financial Development, Investment and Economic Growth: Evidence from Tunisia. Journal of Quantitative Economics 11: 111-29.

Hamdi, Helmi, Sbia Rashid, Abdelaziz Hakimi, and Wafa Khlaifia Hakimi. 2013b. Multivariate Granger causality between foreign direct investment and economic growth in Tunisia. Economics Bulletin 33: 1193-203.

Hansen, Lars Peter. 1982. Large Sample Properties of Generalized Method of Moments Estimators. Econometrica 50: 1029-54. [CrossRef]

Hansen, Lars Peter, and Kenneth Singleton. 1982. Generalized Instrumental Variables of Nonlinear Rational Expectations Models. Econometrica 50: 1269-86. [CrossRef]

Hausman, Jerry. 1978. Specification Tests in Econometrics. Econometrica 46: 1251-71. [CrossRef]

Hong, Liming. 2014. Does and How does FDI Promote the Economic Growth? Evidence from Dynamic Panel Data of Prefecture City in China. IERI Procedia 6: 57-62. [CrossRef] 
Hussein, Muawya Ahmed. 2009. Impacts of foreign direct investment on economic growth in the Gulf Cooperation Council (GCC) Countries. International Review of Business Research Papers 5: 362-76.

Iamsiraroj, Sasi, and Mehmet Ali Ulubaşoğlu. 2015. Foreign direct investment and economic growth: A real relationship or wishful thinking? Economic Modelling 51: 200-13. [CrossRef]

Johansen, Soren. 1988. Statistical Analysis of Cointegration Vectors. Journal of Economic Dynamics and Control 12: 231-54. [CrossRef]

Kao, Chihwa. 1999. Spurious regression and residual-based tests for cointegration in panel data. Journal of Econometrics 90: 1-44. [CrossRef]

Lamsiraroj, Sasi. 2016. The foreign direct investment-economic growth nexus. International Review of Economics and Finance 42: 116-33. [CrossRef]

Lee, Chien-Chiang, and Chung.-Ping Chang. 2009. FDI, financial development, and economic growth: International evidence. Journal of Applied Economics 12: 249-71. [CrossRef]

Levine, Ross, and David Renelt. 1992. A Sensitivity Analysis of Cross-Country Growth Regressions. The American Economic Review 82: 942-63.

Li, Xiaying, and Xiaming Liu. 2004. Foreign Direct Investment and Economic Growth: An Increasingly Endogenous Relationship. Worm Development 33: 393-407. [CrossRef]

Lu, Xun, and Halbert White. 2014. Robustness checks and robustness tests in applied economics. Journal of Econometrics 178: 194-206. [CrossRef]

Mogens, K. Justesen. 2008. The effect of economic freedom on growth revisited: New evidence on causality from a panel of countries 1970-1999. European Journal of Political Economy 24: 642-60.

Nowak-Lehmann, Felicitas, Axel Dreher, Dierk Herzer, Stephan Klasen, and Inmaculada Martínez-Zarzoso. 2012. Does foreign aid really raise per capita income? A time series perspective. Canadian Journal of Economics/Revue Canadienne D'économique 45: 288-313. [CrossRef]

Paakkonen, Jenni. 2010. Economic freedom as driver of growth in transition. Economic Systems 34: 469-79. [CrossRef]

Pedroni, Peter. 1999. Critical Values for Cointegration Tests in Heterogeneous Panels with Multiple Regressors. Oxford Bulletin of Economics and Statistics 61: 653-70. [CrossRef]

Pedroni, Peter. 2004. Panel Cointegration: Asymptotic and Finite Sample Properties of Pooled Time Series Tests with an Application to the PPP Hypothesis. Econometric Theory 20: 597-625. [CrossRef]

Pourshahabi, Farshid, Davoud Mahmoudinia, and Ehsan Salimi Soderjani. 2011. FDI. Human Capital. Economic Freedom and Growth in OECD Countries. Research Journal of International Studies 19: 71-81.

Rajan, Raghuram G, and Luigi Zingales. 1998. Financial dependence and growth. American Economic Review 88: 559-86.

Romer, P. 1993. Idea gaps and object gaps in economic development. Journal of Monetary Economics 32: 543-73. [CrossRef]

Ryan, Compton, Daniel Giedeman, and Gary Hoover. 2011. Panel evidence on economic freedom and growth in the United States. European Journal of Political Economy 27: 423-35.

Saha, Shrabani, Jen-Je Su, and Neil Campbell. 2017. Does Political and Economic Freedom Matter for Inbound Tourism? A Cross-National Panel Data Estimation. Journal of Travel Research 56: 221-34. [CrossRef]

Sayari, Naz, Sari Ramazan, and Shawkat Hammoudeh. 2018. The impact of value added components of GDP and FDI on economic freedom in Europe. Economic Systems 42: 282-94. [CrossRef]

Tan, Yong. 2015. The impacts of risk and competition on bank profitability in China. Journal of International Financial Markets, Institutions and Money 40: 85-110. [CrossRef]

Teece, David. 1977. Technology Transfer by Multinational Firms: The Resource Cost of Transferring Technological Know-how. Economic Journal 87: 242-61. [CrossRef]

Ubeda, Fernando, and Francisco Pérez-Hernández. 2017. Absorptive Capacity and Geographical Distance Two Mediating Factors of FDI Spillovers: A Threshold Regression Analysis for Spanish Firms. Journal of Industry, Competition and Trade 17: 1-28. [CrossRef]

(C) 2018 by the authors. Licensee MDPI, Basel, Switzerland. This article is an open access article distributed under the terms and conditions of the Creative Commons Attribution (CC BY) license (http://creativecommons.org/licenses/by/4.0/). 